\title{
Antioxidant defense and secondary metabolites concentration in hyssop (Hyssopus officinalis L.) plants as affected by salt stress
}

\author{
Zhaleh SOHEILIKHAH ${ }^{1 *}$, Nasser KARIMI ${ }^{2}$, Masoud MODARRESI ${ }^{3}$, Seyed Yahya SALEHI-LISAR ${ }^{1}$, \\ Ali MOVAFEGHI ${ }^{1}$
}

Received January 25, 2021; accepted March 27, 2021.

Delo je prispelo 25. januarja 2021, sprejeto 27. marca 2021.

\begin{abstract}
Antioxidant defense and secondary metabolites concentration in hyssop (Hyssopus officinalis L.) plants as affected by salt stress

Abstract: Salt stress is one of the major limiting factors for plant production, and the quality of medicinal plants is also affected by soil salinity. Hyssop (Hyssopus officinalis L.) plants were cultivated for four weeks in perlite: sand and irrigated with Hoagland nutrient solution containing 0, 50, 100, 150, and $200 \mathrm{mM} \mathrm{NaCl}$. Plants growth was decreased by salt stress while the leaf relative water content was not affected, and the chlorophyll content decreased only by the highest salt concentration (200 mM). Sodium was accumulated at small amounts, indicating a high ability of this species to exclude salt. Soluble sugars and proline were accumulated up to 1.6 and 4.5 fold, respectively. The antioxidant enzymes activity (peroxidase, catalase, ascorbate peroxidase) were increased by the salt treatments, particularly in the leaves. The levels of secondary metabolites (saponins, phenolics, flavonoids, anthocyanins, and iridoids) were all increased under salt stress, and the total antioxidant capacity of alcoholic extract of the leaves and roots was significantly higher in the salt-treated compared with control plants. Our results showed that hyssop is a salt-tolerant species, and the quality of this medicinal plant is improved when grown under saline conditions.
\end{abstract}

Key words: salinity; hyssop; Hyssopus officinalis; secondary metabolites; antioxidant enzymes
Antioksidativna obramba in vsebnost sekundarnih metabolitov v navadnem ožepku (Hyssopus officinalis L.) v razmerah solnega stresa

Izvleček: Solni stres je eden izmed dejavnikov, ki najbolj omejujeje rast rastlin, $\mathrm{v}$ razmerah zasoljenih tal je prizadeta tudi kakovost zdravilnih rastlin. Navadni ožepek (Hyssopus officinalis L.) je bil gojen $\mathrm{v}$ mešanici perlita in peska in zalivan s Hoaglandovo hranilno raztopino, ki je vsebovala $0,50,100$, 150 , and $200 \mathrm{mM} \mathrm{NaCl}$. Rast rastlin se je s solnim stresom zmanjšala, a relativna vsebnost vode $\mathrm{v}$ listih ni bila prizadeta in vsebnost klorofila se je zmanjšala le pri največji koncentraciji (200 mM NaCl). Natrij se je v rastlinah kopičil v majhnih količinah, kar nakazuje sposobnost te vrste, da izloča sol. Vsebnost topnih sladkorjev in prolina se je povečala za 1,6 ,oziroma 4,5 krat. Aktivnost antioksidacijskih encimov (peroksidaze, katalaze, askorbat peroksidaze) se je povečala po obravnavanjih s soljo, še posebej v listih. V razmerah solnega stresa se je povečala raven sekundarnih metabolitov (saponinov, fenolov, flavonoidov, antocianinov in iridoidov), celokupna antioksidacijska sposobnost alkoholnega ekstrakta listov in korenin je bila značilno večja pri rastlinah izpostavljenih soli kot pri kontroli. Rezultati so pokazali, da je navadni ožepek na sol strpna rastlina in, da se kakovost te zdravilne rastline izboljša, če jo gojimo v razmerah slanosti.

Ključne besede: slanost; navadni ožepek; Hyssopus officinalis; sekundarni metaboliti; antioksidacijski encimi

1 Department of Plant Sciences, Faculty of Natural Sciences, University of Tabriz, Tabriz, Iran

2 Department of Biology, Faculty of Science, Razi University, Kermanshah, Iran

3 Department of Pharmacognosy and Pharmaceutical Biotechnology, School of Pharmacy, Kermanshah University of Medical Sciences, Kermanshah, Iran

* Corresponding author, email: zhalehsoheili@gmail.com; 
This paper is part of $\mathrm{PhD}$ thesis of Z.S under cosupervision of A.M \& N.K. M.M \& SY. SL. were the advisors of this thesis.

\section{INTRODUCTION}

Soil salinity is one of the main abiotic stress factors threatening agricultural production worldwide. Salt in the soil is also considered the main factor limiting the dispersal of plants in their natural habitats (Acosta-Motos et al., 2017; Mushtaq et al., 2020). Salinity causes both osmotic and ionic stresses and affects all the plant major processes such as germination, photosynthesis, growth, water and nutrients balances and yield (Parida \& Das, 2005; Parihar et al., 2015).

Salt stress affects the plant's primary metabolism and alters primary metabolites' concentrations, including soluble sugars and amino acids (Gupta and Huang, 2014). Among amino acids, proline plays a pivotal role in the plant's adaptation to salt stress by protecting cells from damages caused by excess accumulation of ions and salt-induced dehydration (Verbruggen and Hermans, 2008). As the second important group of compatible solutes, soluble sugars protect from dehydration and help sustain the structural integrity of plant cells under salt stress (Rosa et al., 2009).

Under environmental stress conditions such as salinity, the generation of higher reactive oxygen species (ROS) causes oxidative stress. It results in membrane damage characterized by elevated levels of malondialdehyde (MDA). Plants employ defensive systems for scavenging ROS and protecting from damaging oxidative reactions through different antioxidant enzymes such as peroxidases (POD), catalase (CAT), and ascorbate peroxidase (APX) (Foyer et al., 1994; Gupta and Huang, 2014; Akyol et al., 2020). Proline protects plant cells from ionic and osmotic stresses and contributes to the scavenging ROS such as hydroxyl radicals (Verbruggen and Hermans, 2008).

In addition to primary metabolism, secondary plant metabolism is also influenced by salt stress (Ahmad and Sharma, 2008). The concentration of secondary metabolites highly depends on plants' growth stage, especially environmental conditions, including light intensity and stress factors such as salt (Ahl and Omer, 2011). Salt stress has a positive or negative impact on secondary metabolites' biosynthesis depending on plant species or the severity of stress (Verma and Shukla, 2015). Salt stress led to about $8-35 \%$ increase in total phenolics and about $35 \%$ increase in total flavonoid content in Portulaca oleracea L. (Alam et al., 2015). An enhancement of antioxidant activity and flavonoid and phenolics contents has also been observed in Cichorium spinosum L. under salt stress (Petropoulos et al., 2017).

In the members of Lamiaceae, salinity may cause substantial changes in the compositions and yield of secondary metabolites (Taarit et al., 2009). Salt stress led to about 20-40\% increase in the total phenolics and flavonoids content in Thymus species (Zrig et al., 2016). Salt stress significantly induced the biosynthesis of some crucial essential oil and phenolic compounds in Salvia mirzayanii Rech.f. \& Esfand. (Valifard et al., 2014). Considering the medicinal application of most plant species from Lamiaceae, it is important to know the effect of salt stress on the quality and quantity of secondary metabolites. The content of secondary metabolites is also a determining factor for the total antioxidant activity of plant extract defined either by FRAP (Ferric Reducing Ability of Plasma) or through DPPH (2, 2-diphenyl-1-picrylhydrazyl) assay (Fukumoto and Mazza, 2000; Sethi et al., 2020).

Hyssop (Hyssopus officinalis L.) is a perennial subshrub belonging to the Lamiaceae family and distributes in the eastern Mediterranean to central Asia (Fathiazad and Hamedeyazdan, 2011). Hyssop is a popular medicinal herb with carminative, tonic, antiseptic, and expectorant properties and is used to remedy congestion, lung complaints, and cardiovascular disorders (Hristova et al., 2015). Extracted essential oils from the shoots of hyssop plants possess a unique aroma and are widely used in the food, pharmaceutical, and cosmetics industries (Kazazi et al., 2007). Different polyphenolic compounds identified in this species contain different glycones and aglycones such as flavonoids, quercetin, apigenin, diosmin, luteolin, and other phenolic compounds such as chlorogenic, ferulic, protocatechuic, syringic, caffeic, and p-hydroxybenzoic acids (Fathiazad and Hamedeyazdan, 2011).

Hyssop is a xerophyte species and is well adapted to drought conditions (Khazaie e al., 2008). Effect of salt stress on the activity of antioxidant enzymes has been investigated in this species (Jahantigh et al., 2016). There is no report, however, on the secondary metabolites levels under salt stress in hyssop plants. This work aimed to investigate the effect of salinity on growth, ROS scavenging activity, the content of various secondary metabolites, and the antioxidant capacity of the leaf and root extract in this species.

\section{MATERIAL AND METHODS}

\subsection{PLANT MATERIAL AND TREATMENTS}

Seeds of hyssop (H. officinalis) were purchased from 
Pakan-Bazr Company (Isfahan, Iran). The seeds were surface-sterilized using $1 \%$ sodium hypochlorite then were sown in the $2 \mathrm{~L}$ pots (15 seeds in each pot) containing sterilized perlite: sand (1:3) mixture and placed at $4{ }^{\circ} \mathrm{C}$ for stratification. After 4 days, the pots were transferred to the greenhouse conditions at $25 / 22{ }^{\circ} \mathrm{C}$ day/ night temperature regimes, at a $16 / 8 \mathrm{~h}$ day/night cycle, and relative humidity of $60 \%$. After germination, plants were irrigated with $20 \%$ Hoagland solution once a week and with $100 \mathrm{ml}$ distilled water twice a week throughout the experiment.

Salt stress was imposed at a four-leaf stage with four $\mathrm{NaCl}$ concentrations $(50,100,150$, and $200 \mathrm{mM})$ applied with irrigation water to the pots gradually within one week. Plants were grown for four weeks after starting salt stress and then were harvested. At harvest, fresh mass (FM) of shoot and roots were determined, and subsamples were taken and immediately frozen in liquid nitrogen and then stored at $-80{ }^{\circ} \mathrm{C}$ until analysis. Another group of samples was oven-dried and, after determination of dry mass (DM), were used for the analysis of secondary metabolites and elemental concentrations.

\subsection{BIOCHEMICAL MEASUREMENTS}

Soluble carbohydrate content was determined according to the phenol-sulfuric acid method (Dubois et al., 1956). Proline was quantified according to the methods of Bates et al. (1973), and the content of soluble proteins was determined using the Bradford method (Bradford, 1976) with bovine serum albumin as standard.

To determine the leaf content of chlorophyll (Chl) and carotenoids, $0.2 \mathrm{~g}$ of fresh leaf samples were homogenized with $2 \mathrm{ml}$ of $80 \%$ acetone and centrifuged at 4000 $g$ for $10 \mathrm{~min}$. After that, the samples' absorbance was recorded by a spectrophotometer (Bausch \& Lomb 70) at 663,645 , and $480 \mathrm{~nm}$, and the contents of pigments were calculated according to the following equations where $\mathrm{A}$ corresponds to the absorbance (Flores-de-Santiago et al., 2016):

Chl a $=12.21 \mathrm{~A}_{663}-2.81 \mathrm{~A}_{646}$

$\mathrm{Chl} b=20.13 \mathrm{~A}_{646}-5.03 \mathrm{~A}_{663}$

Carotenoids $=\left[1000 \mathrm{~A}_{470}-3.27(\mathrm{Chl} \mathrm{a})-104(\mathrm{Chl} b)\right] / 229$

The leaf relative water content (RWC, \%) was measured according to the following equation:

$R W C(\%)=[(F M-D M) /(T M-D M)] \times 100$

For determination of turgid mass (TM), leaf disks ( 5 $\mathrm{mm}$ diameter) were submerged for $5 \mathrm{~h}$ in distilled water, thereafter, they were blotted dry gently on a paper towel and weighed.

\subsection{OXIDATIVE STRESS MARKERS AND ACTIVITIES OF ANTIOXIDANT ENZYMES}

Sergiev et al. (1997) method with slight modification was used for quantification of $\mathrm{H}_{2} \mathrm{O}_{2}$ content. $100 \mathrm{mg}$ of samples were ground in liquid nitrogen, extracted with trichloroacetic acid (TCA) in an ice bath, centrifuged at $13,000 \mathrm{~g}$ for $15 \mathrm{~min}$. The $500 \mu \mathrm{l}$ of supernatant was added to potassium phosphate buffer ( $\mathrm{pH}$ 7.0), and the $\mathrm{H}_{2} \mathrm{O}_{2}$ content was determined based on supernatant absorbance at $390 \mathrm{~nm}$. Malondialdehyde (MDA) content was evaluated by the method of Heath and Packer (1968). $100 \mathrm{mg}$ of samples were homogenized in $1 \mathrm{ml} 0.1 \%(\mathrm{v} / \mathrm{v})$ TCA and centrifuged at $12,000 \mathrm{~g}$ for $10 \mathrm{~min}$. The extracted supernatant $(0.1 \mathrm{ml})$ was mixed with $20 \%$ TCA containing $0.5 \%(\mathrm{w} / \mathrm{v})$ thiobarbituric acid (TBA). The mixture was incubated at $100{ }^{\circ} \mathrm{C}$ for $10 \mathrm{~min}$ then centrifuged at $10,000 \mathrm{~g}$ for $15 \mathrm{~min}$. TBA reactive substances' content was calculated based on the difference in absorbance at 532 and $600 \mathrm{~nm}$ using an extinction coefficient of 155 $\mathrm{mM}^{-1} \mathrm{~cm}^{-1}$.

For assay of catalase (CAT), peroxidase (POD), and ascorbate peroxidase (APX), $100 \mathrm{mg}$ of the samples was extracted in $5 \mathrm{ml}$ of $100 \mathrm{mM}$ phosphate buffer. The homogenate was then centrifuged for $10 \mathrm{~min}$ and used for enzyme assays. CAT activity was analyzed by Beers and Sizer (1952) method. The $2 \mathrm{ml}$ of reaction mixture containing $100 \mathrm{mM}$ potassium phosphate buffer $(\mathrm{pH}$ 7.0) was mixed with $400 \mathrm{ml}$ of $6 \% \mathrm{H}_{2} \mathrm{O}_{2}$ and $100 \mu$ of enzyme extract. CAT activity was calculated to reduce the $\mathrm{H}_{2} \mathrm{O}_{2}$ absorption at a wavelength of $240 \mathrm{~nm}$ using an extinction coefficient of $0.036 \mathrm{mM}^{-1} \mathrm{~cm}^{-1}$. POD activity was measured by the method of Lin and Kao (1999). The reaction mixture $(2 \mathrm{ml})$ contained potassium phosphate buffer (50 mM, pH 7), guaiacol solution $(9 \mathrm{mM}), \mathrm{H}_{2} \mathrm{O}_{2}(19 \mathrm{mM})$ and root or leaf extract $(100 \mu \mathrm{l})$. POD activity calculated the absorbance changes at $470 \mathrm{~nm}$ using the extinction coefficient of $26.6 \mathrm{mM}^{-1} \mathrm{~cm}^{-1}$. For assay of APX, the reaction mixture contained $250 \mathrm{mM}$ phosphate buffer ( $\mathrm{pH} 7$ ), $1.2 \mathrm{mM} \mathrm{H}_{2} \mathrm{O}_{2}, 0.5 \mathrm{mM}$ ascorbic acid, and $0.1 \mathrm{mM}$ EDTA. The reaction was started by adding $\mathrm{H}_{2} \mathrm{O}_{2}$ to the mixture. Total APX activity was calculated to reduce the absorbance at $290 \mathrm{~nm}$ for $2 \mathrm{~min}$ using the extinction coefficient of ascorbic acid $\left(2.8 \mathrm{mM}^{-1} \mathrm{~cm}^{-1}\right)$ (Dazy et al., 2008).

\subsection{SECONDARY METABOLITES QUANTIFICATION}

For analyzing secondary metabolites, $100 \mathrm{mg}$ of leaf or root dried samples were dissolved in $80 \%$ ethanol (5 $\mathrm{ml}$ ) and sonicated for $20 \mathrm{~min}$ at room temperature. The resulted mixture was centrifuged at $3,000 \mathrm{~g}$ for $15 \mathrm{~min}$. 
The extraction was repeated three times, and the supernatants were pooled and stored until analysis.

A colorimetric method was used to determine the total amount of saponins (Hiai et al., 1975). In a test tube, $0.5 \mathrm{ml}$ of plant ethanol extract was mixed with $0.5 \mathrm{ml}$ of vanillin and $5 \mathrm{ml}$ of $72 \%$ sulfuric acid. The mixture was shaken and heated for $10 \mathrm{~min}$ at $60{ }^{\circ} \mathrm{C}$ in a water bath. After cooling in the water at room temperature, the extract's absorbance was determined spectrophotometrically at $545 \mathrm{~nm}$. To determine the concentration of the total phenolics, $2.5 \mathrm{ml}$ of Folin-Ciocalteu-Deniz indicator and $2.5 \mathrm{ml}$ of $2 \%$ sodium carbonate solution were added to $0.5 \mathrm{ml}$ plant ethanol extract. The resulting mixture was homogenized and incubated in the dark for $30 \mathrm{~min}$. The absorbance of the solution was measured spectrophotometrically at $750 \mathrm{~nm}$ (Seevers et al., 1971). The total flavonoids concentration was determined using the aluminum chloride colorimetric method (Zhishen et al., 1999). The extract's $0.5 \mathrm{ml}$ was mixed with $4.5 \mathrm{ml}$ of distilled water and $0.5 \mathrm{ml}$ of $5 \%$ sodium nitrite solution. After $5 \mathrm{~min}, 0.5 \mathrm{ml}$ of $10 \%$ aluminum chloride was added, and the mixture was incubated for $6 \mathrm{~min}$. After that, $4 \mathrm{ml}$ of $1 \mathrm{M} \mathrm{NaOH}$ was added, and after $15 \mathrm{~min}$, the absorbance of the mixture was read at $510 \mathrm{~nm}$ by a spectrophotometer. Quercetin was used for the creation of a standard curve. For analyzing the total anthocyanins concentration, $0.2 \mathrm{ml}$ of alcohol extract was diluted separately with $4.8 \mathrm{ml}$ potassium chloride $(\mathrm{pH} 1)$ and sodium acetate buffer ( $\mathrm{pH} 4.5)$. The solutions were incubated in the dark for $15 \mathrm{~min}$. The absorbance of both groups of samples was determined at 510 and $700 \mathrm{~nm}$, and the concentration of anthocyanins (A) was calculated according to the following equation and reported as cyanidin-3-Oglucoside equivalent using an extinction coefficient of $26.9 \mathrm{mM}^{-1} \mathrm{~cm}^{-1}$ (Giusti and Wrolstad, 2001):

$\mathrm{A}=\left[\left(\mathrm{A}_{510} \mathrm{~nm}-\mathrm{A}_{700} \mathrm{~nm}\right)\right]_{\mathrm{pH} 1.0}-\left[\left(\mathrm{A}_{510} \mathrm{~nm}-\mathrm{A}_{700} \mathrm{~nm}\right)\right]_{\mathrm{pH} 4.5}$

A colorimetric method based on the color reaction of acobin with glycine was used to determine the total iridoid concentration (Narayanan and Akamanchi, 2003). One $\mathrm{ml}$ of ethanol extract was mixed with $2 \mathrm{ml}$ distilled water, $1 \mathrm{ml}$ of $10 \%$ glycine, and $1 \mathrm{ml}$ sulfuric acid $(0.1$ $\mathrm{M})$. The mixture was shaken and heated in a water bath $\left(95{ }^{\circ} \mathrm{C}\right)$ for $1 \mathrm{~h}$. After cooling at room temperature, the absorbance was measured at $554 \mathrm{~nm}$.

\subsection{DETERMINATION OF TOTAL ANTIOXIDANT ACTIVITY}

Different plant extract concentrations in methanol $\left(10,25,50,100,250\right.$, and $\left.500 \mu \mathrm{g} \mathrm{ml}^{-1}\right)$ were prepared and

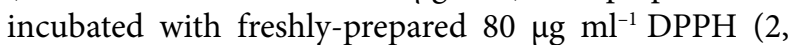

2-diphenyl-1-picrylhydrazyl). The mixtures were shaken and placed in the dark for $30 \mathrm{~min}$, then the absorbance of the samples in parallel with a solution without plant extract (as blank) was read at $517 \mathrm{~nm}$. The inhibition (\%) of DPPH radical formation was calculated according to the following equation:

Inhibition $(\%)=\left[\left(\mathrm{A}_{\text {blank }}-\mathrm{A}_{\text {sample }}\right) / \mathrm{A}_{\text {blank }}\right] \times 100$

Plant extract's antioxidant activity was reported as the sample concentration providing $50 \%$ inhibition $\left(\mathrm{IC}_{50}\right)$ calculated by plotting inhibition percentages against the samples' concentration (Sarkar et al., 2006).

\subsection{DETERMINATION OF ELEMENTS CONCENTRATIONS}

To determine potassium $(\mathrm{K})$ and sodium $(\mathrm{Na})$ concentrations, $100 \mathrm{mg}$ milled oven-dried samples were digested in concentrated nitric acid overnight, then heated at $80{ }^{\circ} \mathrm{C}$ for one hour and dissolved in $1 \% \mathrm{HCl}$. The concentrations of $\mathrm{K}$ and $\mathrm{Na}$ were determined by flame photometry (Kalra, 1997).

\subsection{STATISTICAL ANALYSIS}

The experiment was undertaken as a completely randomized block design with three pots as independent replicates for each treatment. Data were presented as means \pm standard deviation (SD). Comparison of means was performed by Tukey test $(p<0.05)$ using SPSS (version 23, for Windows; SPSS Inc., Chicago, IL, USA).

\section{RESULTS AND DISCUSSION}

Plants' growth was expectedly decreased under salt stress conditions (Fig. 1). A significant effect of salt stress on the shoot and root fresh weight was observed at 100 $\mathrm{mM}$ salt and higher. Dry biomass of plants was depressed up to $75 \%$ at a salt concentration of $200 \mathrm{mM}$. Shoot height and length of the taproot significantly decreased by $50 \mathrm{mM}$ salt and higher (Fig. 2).

The leaf content of $\mathrm{Chl}$ a and $\mathrm{Chl} b$ were not affected by salt concentration up to 150 and $100 \mathrm{mM} \mathrm{NaCl}$, respectively. Leaf carotenoid content and RWC, were not significantly influenced by applied salt levels (Table 1).

Activities of all three analyzed antioxidant enzymes were higher in salt-stressed plants both in the leaves and roots (Fig. 3). At $200 \mathrm{mM}$ salt concentration, the leaf activities of POD, CAT and APX increased up to 2.3, 6.3 and 6.9 fold, respectively, compared to the control treat- 


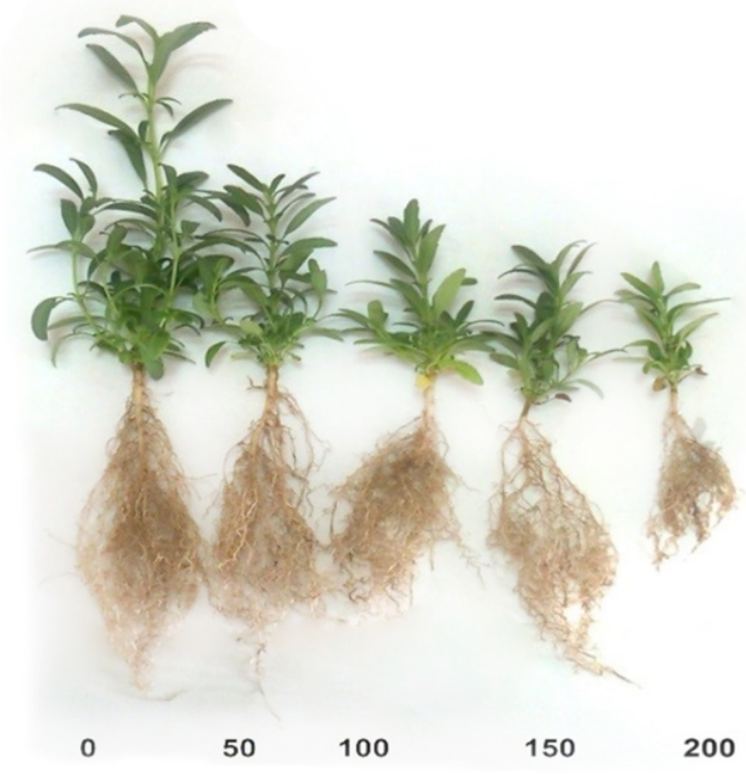

Figure 1: Hyssop (Hyssopus officinalis L.) plants grown for 4 weeks under control or different salt concentrations (50, 100, 150 and $200 \mathrm{mM} \mathrm{NaCl}$ ) under greenhouse conditions.

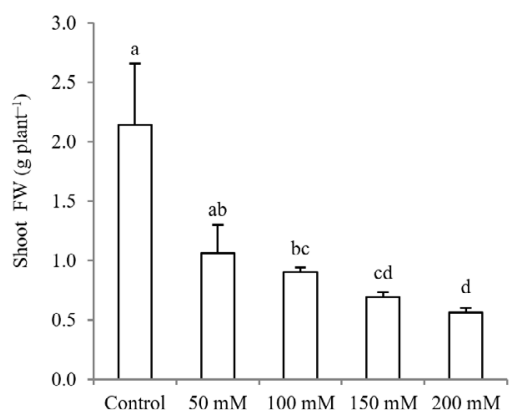

Salt treatment

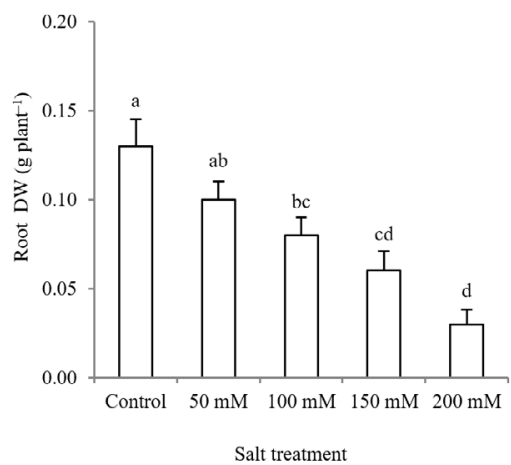

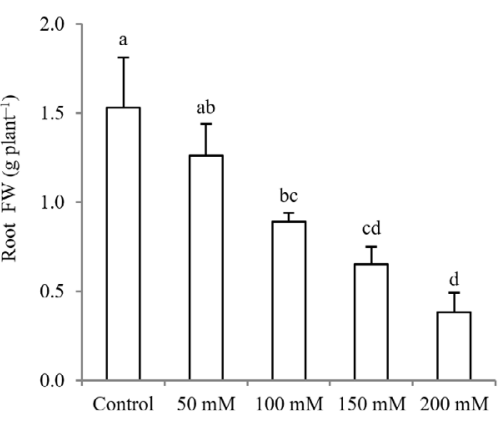

Salt treatment

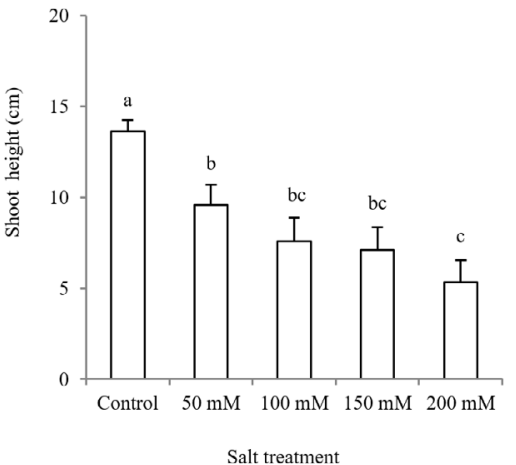

Figure 2: Fresh and dry biomass (g plant $\left.{ }^{-1}\right)$, shoot height and root length ( $\left.\mathrm{cm}\right)$ of hyssop (Hyssopus officinalis L.) pplants grown for 4 weeks under control or different salt concentrations $(50,100,150$ and $200 \mathrm{mM} \mathrm{NaCl})$ under greenhouse conditions. Bars indicated by the same letter are not significantly different $(p<0.05)$. 
Table 1: Content of chlorophyll (Chl) $a, b$ and carotenoids (mg g $\left.{ }^{-1} \mathrm{FM}\right)$ and relative water content (RWC, \%) in the leaves of hyssop (Hyssopus officinalis L.) plants grown for 4 weeks under control or different salt concentrations (50, 100, 150 and $200 \mathrm{mM}$ $\mathrm{NaCl})$ under greenhouse conditions. Data of each column indicated by the same letter are not significantly different $(p<0.05)$.

\begin{tabular}{lcccc}
\hline $\mathrm{NaCl}$ concentration & Chl $a$ & Chl $b$ & Carotenoids & RWC \\
\hline Control & $3.01 \pm 0.27^{\mathrm{a}}$ & $1.27 \pm 0.18^{\mathrm{a}}$ & $4.95 \pm 0.53^{\mathrm{a}}$ & $0.58 \pm 0.05^{\mathrm{a}}$ \\
$50 \mathrm{mM}$ & $2.95 \pm 0.21^{\mathrm{a}}$ & $1.07 \pm 0.06^{\mathrm{a}}$ & $5.40 \pm 3.74^{\mathrm{a}}$ & $0.50 \pm 0.11^{\mathrm{a}}$ \\
$100 \mathrm{mM}$ & $2.18 \pm 0.04^{\mathrm{ab}}$ & $1.09 \pm 0.01^{\mathrm{a}}$ & $3.74 \pm 0.13^{\mathrm{a}}$ & $0.55 \pm 0.12^{\mathrm{a}}$ \\
$150 \mathrm{mM}$ & $2.48 \pm 0.19^{\mathrm{a}}$ & $0.74 \pm 0.07^{\mathrm{b}}$ & $4.19 \pm 0.35^{\mathrm{a}}$ & $0.46 \pm 0.04^{\mathrm{a}}$ \\
$200 \mathrm{mM}$ & $1.36 \pm 0.79^{\mathrm{b}}$ & $0.76 \pm 0.09^{\mathrm{b}}$ & $2.51 \pm 0.25^{\mathrm{a}}$ & $0.49 \pm 0.03^{\mathrm{a}}$ \\
\hline
\end{tabular}
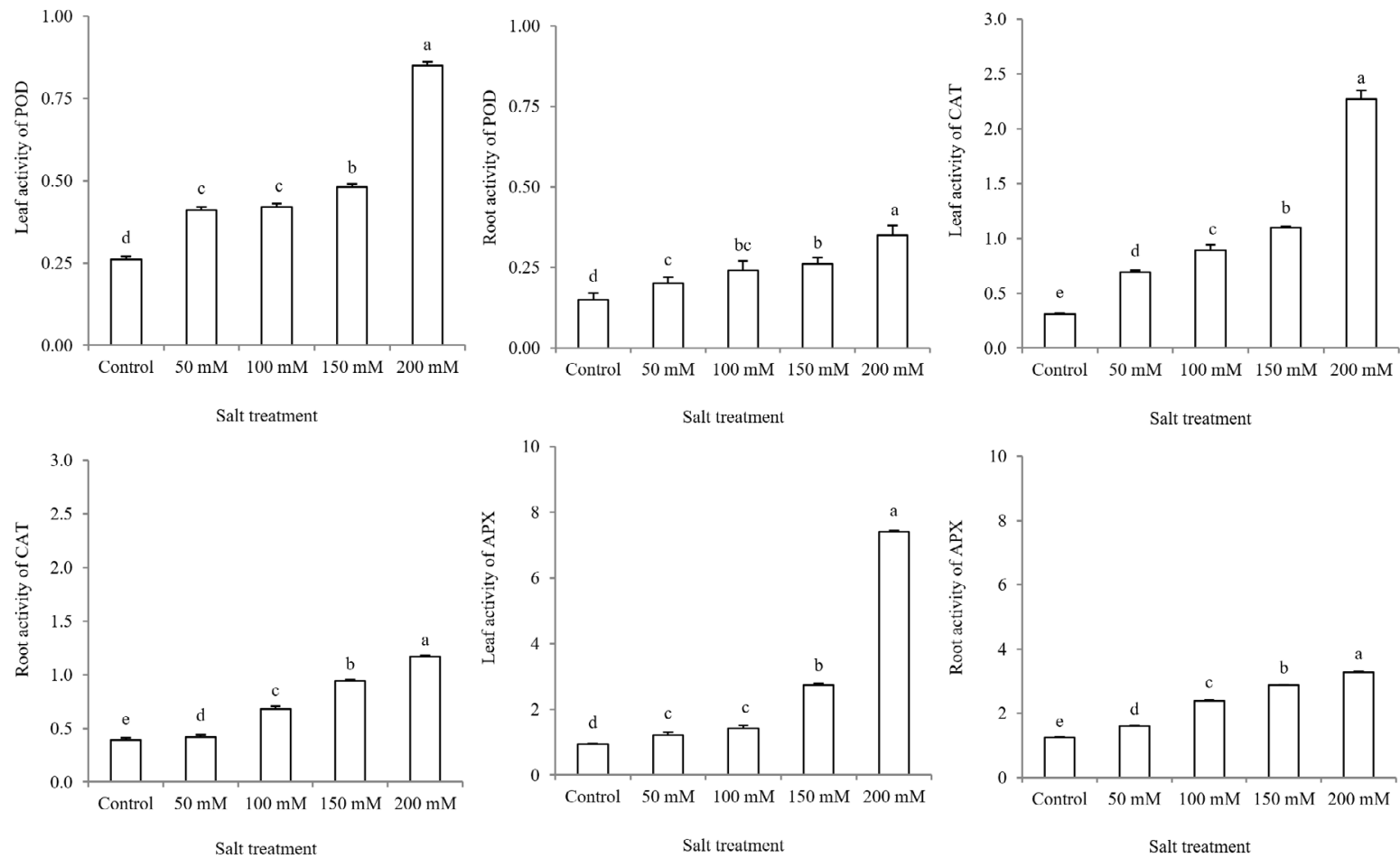

Figure 3: Activity of peroxidase $\left(\mu \mathrm{mol} \mathrm{mg} \mathrm{m}^{-1}\right.$ protein $\left.\mathrm{min}^{-1}\right)$, catalase $\left(\mu \mathrm{mol} \mathrm{mg} \mathrm{m}^{-1}\right.$ protein $\left.\mathrm{min}^{-1}\right)$ and ascorbate peroxidase $(\mu \mathrm{mol}$ $\mathrm{mg}^{-1}$ protein $\left.\mathrm{min}^{-1}\right)$ in the leaves and roots of hyssop $($ Hyssopus officinalis L.) piants grown for 4 weeks under control or different salt concentrations $(50,100,150$ and $200 \mathrm{mM} \mathrm{NaCl})$ under greenhouse conditions. Bars indicated by the same letter are not significantly different $(p<0.05)$.

ment. In the roots, the activities of POD, CAT and APX were 1.3, 2.0 and 1.6 fold higher than the control plants (Fig. 3).

The soluble sugar content increased gradually in response to increasing salt levels in the medium, both in the leaves and roots. The extent of the increase was higher for the leaves (60\% at $200 \mathrm{mM}$ salt) than the roots $(20 \%$ at $200 \mathrm{mM}$ salt). The content of soluble proteins decreased by salt stress both in the leaves and roots. However, different salt levels did not differ in their effect on the root protein content, while in the leaves, it was continuously decreased by increasing salt levels (Table 2). Proline was accumulated both in the leaves and roots upon exposure to salt stress. In the leaves, proline content responded to low salt level $(50 \mathrm{mM})$ and accumulated up to 4.5 fold in the presence of $200 \mathrm{mM}$ salt. In comparison, in the roots, salt's significant effect was not observed at a low level (50 mM) and accumulated to much less extent, i,e, 1.8 fold under $200 \mathrm{mM}$ salt. The concentration of $\mathrm{K}$ was steadily decreased under salt treatment while that of $\mathrm{Na}$ increased both in the leaves and roots (Table 2).

Leaf content of MDA was increased by salt stress both in the leaves and roots. The treatment effect was more prominent in the roots with up to 2.3 fold MDA accumulation at the salt treatment of $200 \mathrm{mM}$, while the corresponding value for the leaves was only 1.2 fold. The 
Table 2: Contents of soluble sugars ( $\left.\mathrm{mg} \mathrm{g}^{-1} \mathrm{FM}\right)$, soluble proteins $\left(\mathrm{mg} \mathrm{g}^{-1} \mathrm{FM}\right)$, proline $\left(\mu \mathrm{mol} \mathrm{g} \mathrm{g}^{-1} \mathrm{M}\right)$, potassium and sodium (mg $\left.\mathrm{g}^{-1} \mathrm{DM}\right)$ in the leaves and roots of hyssop ( trations $(50,100,150$ and $200 \mathrm{mM} \mathrm{NaCl})$ under greenhouse conditions. Data of each column indicated by the same letter are not significantly different $(p<0.05)$.

\begin{tabular}{lccccc}
\hline \multirow{2}{*}{$\mathrm{NaCl}$ concentration } & Soluble sugars & Soluble proteins & Proline & Potassium & Sodium \\
\cline { 2 - 6 } & & \multicolumn{3}{c}{ Leaves } \\
\hline Control & $21.43 \pm 0.84^{\mathrm{d}}$ & $12.3 \pm 0.02^{\mathrm{a}}$ & $5.03 \pm 0.01^{\mathrm{e}}$ & $4.72 \pm 0.15^{\mathrm{a}}$ & $2.39 \pm 0.09^{\mathrm{d}}$ \\
$50 \mathrm{mM}$ & $23.05 \pm 1.27^{\mathrm{cd}}$ & $10.7 \pm 0.10^{\mathrm{b}}$ & $5.88 \pm 0.01^{\mathrm{d}}$ & $4.39 \pm 0.06^{\mathrm{b}}$ & $3.63 \pm 0.24^{\mathrm{c}}$ \\
$100 \mathrm{mM}$ & $26.23 \pm 1.67^{\mathrm{bc}}$ & $9.61 \pm 0.23^{\mathrm{c}}$ & $6.53 \pm 0.05^{\mathrm{c}}$ & $4.26 \pm 0.01^{\mathrm{b}}$ & $4.13 \pm 0.13^{\mathrm{c}}$ \\
$150 \mathrm{mM}$ & $28.27 \pm 0.32^{\mathrm{b}}$ & $9.04 \pm 0.36^{\mathrm{d}}$ & $12.2 \pm 0.10^{\mathrm{b}}$ & $3.66 \pm 0.01^{\mathrm{c}}$ & $4.84 \pm 0.26^{\mathrm{b}}$ \\
$200 \mathrm{mM}$ & $34.05 \pm 1.90^{\mathrm{a}}$ & $7.01 \pm 0.07^{\mathrm{e}}$ & $22.5 \pm 0.03^{\mathrm{a}}$ & $3.29 \pm 0.15^{\mathrm{d}}$ & $5.58 \pm 0.40^{\mathrm{a}}$ \\
\hline & & & & \\
\hline $\mathrm{Control}$ & $31.27 \pm 0.16^{\mathrm{b}}$ & $10.8 \pm 1.64^{\mathrm{a}}$ & $2.70 \pm 0.27^{\mathrm{d}}$ & $7.16 \pm 0.10^{\mathrm{a}}$ & $0.35 \pm 0.01^{\mathrm{e}}$ \\
$50 \mathrm{mM}$ & $31.41 \pm 0.07^{\mathrm{b}}$ & $8.44 \pm 0.02^{\mathrm{b}}$ & $2.94 \pm 0.20^{\mathrm{cd}}$ & $6.56 \pm 0.10^{\mathrm{b}}$ & $0.59 \pm 0.01^{\mathrm{d}}$ \\
$100 \mathrm{mM}$ & $33.51 \pm 0.12^{\mathrm{b}}$ & $7.51 \pm 0.02^{\mathrm{b}}$ & $3.57 \pm 0.13^{\mathrm{bc}}$ & $6.26 \pm 0.10^{\mathrm{c}}$ & $0.75 \pm 0.07^{\mathrm{c}}$ \\
$150 \mathrm{mM}$ & $36.63 \pm 1.81^{\mathrm{a}}$ & $7.14 \pm 0.05^{\mathrm{b}}$ & $4.05 \pm 0.14^{\mathrm{b}}$ & $5.46 \pm 0.10^{\mathrm{d}}$ & $1.05 \pm 0.02^{\mathrm{b}}$ \\
$200 \mathrm{mM}$ & $37.51 \pm 0.75^{\mathrm{a}}$ & $6.76 \pm 0.20^{\mathrm{b}}$ & $4.79 \pm 0.37^{\mathrm{a}}$ & $4.36 \pm 0.10^{\mathrm{e}}$ & $1.42 \pm 0.07^{\mathrm{a}}$ \\
\hline
\end{tabular}
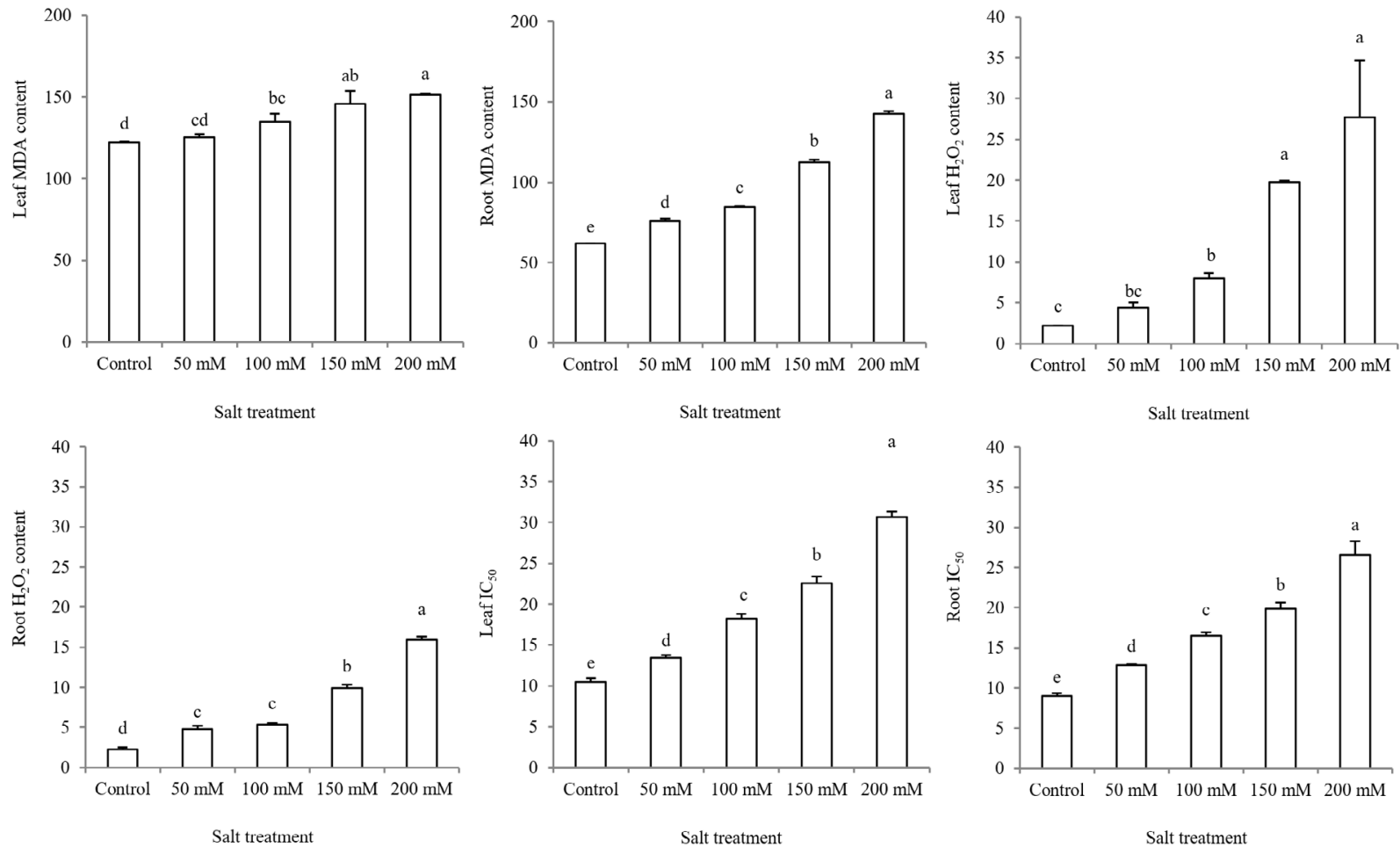

Figure 4: Contents of malondialdehyde (MDA, $\left.\mu \mathrm{mol} \mathrm{g}{ }^{-1} \mathrm{FM}\right), \mathrm{H}_{2} \mathrm{O}_{2}\left(\mu \mathrm{mol} \mathrm{g} \mathrm{g}^{-1} \mathrm{FM}\right)$ and total antioxidant activity (IC $\left.{ }_{50}\right)$ in the leaves and roots of hyssop (Hyssopus officinalis L.) pplants grown for 4 weeks under control or different salt concentrations (50, 100, 150 and $200 \mathrm{mM} \mathrm{NaCl})$ under greenhouse conditions. Bars indicated by the same letter are not significantly different $(p<0.05)$. 
Table 3: Concentrations of saponins ( $\left.\mathrm{mg} \mathrm{g}^{-1} \mathrm{DM}\right)$, total phenolics ( $\left.\mathrm{mg} \mathrm{g}^{-1} \mathrm{DM}\right)$, total flavonoids $\left(\mu \mathrm{g} \mathrm{g}^{-1} \mathrm{DM}\right)$, anthocyanins $\left(\mu \mathrm{g} \mathrm{g} \mathrm{g}^{-1}\right.$ $\mathrm{DM})$ and iridoids ( $\left.\mathrm{mg} \mathrm{g}^{-1} \mathrm{DM}\right)$ in the leaves and roots of hyssop $[($ Hyssopus officinalis L.) pplants grown for 4 weeks under control or different salt concentrations $(50,100,150$ and $200 \mathrm{mM} \mathrm{NaCl})$ under greenhouse conditions. Data of each column indicated by the same letter are not significantly different $(p<0.05)$.

\begin{tabular}{|c|c|c|c|c|c|}
\hline \multirow{2}{*}{$\mathrm{NaCl}$ concentration } & Saponins & Phenolics & Flavonoids & Anthocyanins & Iridoids \\
\hline & \multicolumn{5}{|c|}{ Leaves } \\
\hline Control & $330 \pm 2.8^{c}$ & $19.3 \pm 0.10^{d}$ & $75.4 \pm 3.96^{d}$ & $10.15 \pm 0.57^{\mathrm{d}}$ & $50.7 \pm 1.59^{d}$ \\
\hline $50 \mathrm{mM}$ & $371 \pm 24.7^{c}$ & $22.1 \pm 0.98^{c}$ & $87.6 \pm 3.22^{c}$ & $18.70 \pm 0.62^{\mathrm{c}}$ & $55.0 \pm 2.57^{\mathrm{cd}}$ \\
\hline $100 \mathrm{mM}$ & $475 \pm 83.6^{c}$ & $24.4 \pm 0.33^{b}$ & $93.9 \pm 1.83^{c}$ & $20.55 \pm 0.78^{c}$ & $73.7 \pm 3.13^{b c}$ \\
\hline $150 \mathrm{mM}$ & $644 \pm 54.6^{b}$ & $25.7 \pm 0.90^{a b}$ & $109 \pm 4.58^{b}$ & $26.25 \pm 0.83^{b}$ & $92.2 \pm 5.78^{b}$ \\
\hline \multirow[t]{2}{*}{$200 \mathrm{mM}$} & $801 \pm 68.9^{a}$ & $27.4 \pm 0.48^{\mathrm{a}}$ & $118 \pm 2.37^{\mathrm{a}}$ & $50.09 \pm 1.98^{\mathrm{a}}$ & $129.1 \pm 15.2^{a}$ \\
\hline & \multicolumn{5}{|c|}{ Roots } \\
\hline Control & $390 \pm 23.7^{c}$ & $45.31 \pm 1.22^{\mathrm{d}}$ & $199 \pm 18.31^{\mathrm{c}}$ & $0.90 \pm 0.10^{d}$ & $70.5 \pm 0.33^{a}$ \\
\hline $50 \mathrm{mM}$ & $446 \pm 10.1^{c}$ & $48.79 \pm 0.82^{\mathrm{cd}}$ & $224 \pm 1.64^{b c}$ & $1.50 \pm 0.10^{\mathrm{d}}$ & $75.3 \pm 0.98^{a}$ \\
\hline $100 \mathrm{mM}$ & $610 \pm 109^{b}$ & $52.75 \pm 0.38^{\mathrm{bc}}$ & $239 \pm 8.38^{b}$ & $2.52 \pm 0.50^{c}$ & $76.8 \pm 0.18^{a}$ \\
\hline $150 \mathrm{mM}$ & $755 \pm 18.3^{a}$ & $55.03 \pm 0.43^{b}$ & $249 \pm 1.77^{a b}$ & $4.00 \pm 0.56^{b}$ & $78.5 \pm 0.64^{a}$ \\
\hline $200 \mathrm{mM}$ & $859 \pm 5.81^{a}$ & $59.39 \pm 3.10^{a}$ & $267 \pm 9.39^{\mathrm{a}}$ & $6.98 \pm 0.07^{\mathrm{a}}$ & $75.9 \pm 6.79^{a}$ \\
\hline
\end{tabular}

content of $\mathrm{H}_{2} \mathrm{O}_{2}$ was consistently increased by increasing salt level. The $\mathrm{H}_{2} \mathrm{O}_{2}$ accumulation in response to higher salt levels (150 and $200 \mathrm{mM}$ ) was more prominent in the leaves than in the roots. The total antioxidant activity $\left(\mathrm{IC}_{50}\right)$ was increased up to 2.9 fold in the salt-stressed plants (Fig. 4).

The leaf and root concentrations of all analyzed secondary metabolites were increased by exposure to salt stress in the leaves and roots except iridoids in the roots that remained unchanged (Table 3). Lower salt level $(50 \mathrm{mM})$ was effective in the increasing phenolics, flavonoids, and anthocyanins in the leaves, while in the roots, a significant effect was observed by higher salt level $(100 \mathrm{mM})$. The extent of salt-induced increase in the concentration of analyzed secondary metabolites was in the range of 1.5-2.5 fold except for anthocyanins. This metabolite showed up to 4.9 and 7.8 fold increase upon exposure to $200 \mathrm{mM}$ salt in the leaves and roots, respectively (Table 3).

\section{DISCUSSION}

\subsection{EFFECT OF SALT STRESS ON GROWTH, NA CONCENTRATION AND LEAF CHL CONTENT}

Hyssop is a drought-tolerant species (Khazaie e al., 2008); however, its salt tolerance has not been studied so far. Our data demonstrated that hyssop is also tolerant to salinity stress as the plants in our study survived after 4 weeks of salt treatment of $200 \mathrm{mM}$. Such high salt toler- ance has been rarely reported in the members of Lamiaceae. In the studies on the salt tolerance in other Lamiaceae species such as Thymus, Perilla, and Salvia, much higher growth inhibition by salt has been reported, and plants were killed by salt concentrations higher than 100 mM (Paiva et al., 2018; Bistgani et al., 2019; Salachna et al., 2019).

The Na concentration data showed that this species is a Na-excluder salt-tolerant plant and can avoid root $\mathrm{Na}$ uptake. The low $\mathrm{Na}$ accumulation in the roots and leaves was accompanied by stable amounts of RWC showing that this species maintains tissue water content despite exposure to low water potentials in the rooting medium. On the other hand, a constitutively lower RWC (0.49-0.58 \%) shows that these species cope with low water potentials through passive water content reduction. A similar mechanism for salt tolerance has been observed in Thellungiella, a halophyte close relative of Arabidopsis (Lugan et al., 2010).

In agreement with the conclusion mentioned above on high salt tolerance in hyssop plants, leaf $\mathrm{Chl}$ content remained unaffected by salt treatment up to $150 \mathrm{mM}$ suggesting that leaf photosynthetic capacity remained mainly unaffected under these conditions. The maintenance of photosynthesis and carbon metabolism may help plants retain an ability to synthesize organic osmolytes, including soluble sugars and proline (Chaves et al., 2009). These two organic osmolytes were accumulated in the leaves up to 1.6 and 4.5 fold, respectively, which may contribute significantly to plants' osmotic homeostasis under salt stress conditions. In addition to osmotic functions, 
these osmolytes contribute to protecting cell structures, ROS scavenging, and nitrogen and carbon sources under stress conditions (Verbruggen and Hermans, 2008; Mattioli et al., 2009; Rosa et al., 2009).

\subsection{EFFECT OF SALT STRESS ON THE ACTIVITY OF ROS ACCUMULATION, SCAVENGING AND MEMBRANE INTEGRITY}

The activities of ROS scavenging enzymes were expectedly increased by salt treatment both in the leaves and roots. The salt-induced activity of all three analyzed enzymes was higher in the leaves compared with the roots that may contribute to high protection of leaves against salt-induced damage. Better protection of leaves than roots was confirmed by the maintenance of a high Chl content under high salinity treatments and much less increase of MDA content under salt stress $(24 \%$ at 200 $\mathrm{mM}$ salt) compared with the roots $(130 \%$ at $200 \mathrm{mM}$ salt).

Nevertheless, the accumulation of $\mathrm{H}_{2} \mathrm{O}_{2}$ was higher in the leaf than in the roots indicating that higher enzyme activities were not sufficient for inhibition of $\mathrm{H}_{2} \mathrm{O}_{2}$ accumulation in the leaves. Although $\mathrm{H}_{2} \mathrm{O}_{2}$ belongs to ROS, it is known to be much less damaging in comparison to superoxide and hydroxyl radicals (Cheng et al., 2006). The prevailing effect of $\mathrm{H}_{2} \mathrm{O}_{2}$ is a signaling role. It has been observed that $\mathrm{H}_{2} \mathrm{O}_{2}$ is an important signal that is raised under salt stress and is responsible for the activation of various defense pathways in salt-stressed plants (Shu-Hsien et al., 2005). We suggest that the higher capability of leaves for $\mathrm{H}_{2} \mathrm{O}_{2}$ accumulation, and activation of defense pathways may be partly responsible for higher protection of leaves against salt stress than the roots.

\subsection{EFFECT OF SALT STRESS ON THE CONCENTRATION OF SECONDARY METABOLITES}

The concentration of all analyzed secondary metabolites was higher in the salt-stressed hyssop plants in our study. The effect of salt treatment on the levels of phenolics, flavonoids, and anthocyanins has been reported in other Lamiaceae species (Kotagiri et al., 2017; Bistgani et al., 2019; Salachna et al., 2019; Becerra-Gudiño et al., 2019). However, in hyssop, the quantity of bioactive compounds as affected by salinity has not been investigated so far. Our study is also the first report on the effect of salt stress on the saponins and iridoids. Iridoids are a type of monoterpenoids found in plants, mainly as glyco- sides (Wang et al., 2020). The iridoids produced by plants act as a defense against herbivores or microorganisms (Fuchs et al., 2004). From a medicinal point of view, these compounds have wound-healing and anti-inflammatory effects with therapeutic potential for Alzheimer's and Parkinson's diseases (Dinda et al., 2019; Hussain et al., 2019). Saponins with one or more hydrophilic glycoside moieties combined with a lipophilic triterpene molecule (El Aziz et al., 2019) exhibit medicinal properties such as hemolytic factor, anti-inflammatory, antibacterial, antifungal, antiviral, anticancer, and cholesterol-lowering action in animals and human (Sparg et al., 2004). Besides, saponins formed the backbone of modern medicine or drugs and were considered a starting precursor for the semi-synthesis of steroidal drugs in the pharmaceutical industry (Netala et al., 2015).

It is noteworthy that higher concentrations of the secondary metabolites accompanied by reduction of biomass suggests a 'concentration-effect' in our hyssop plants. Nonetheless, it indicates that salt treatment did not inhibit the secondary metabolism in this species.

\subsection{EFFECT OF SALT STRESS ON THE ANTIOXIDANT ACTIVITY OF LEAF AND ROOT EXTRACT}

The DPPH scavenging activity is defined as the antioxidant activity of food and medicinal plants (Fukumoto and Mazza 2000; Sethi et al., 2020), has been reported for hyssop plants (Fathiazad et al., 2011; Pirbalouti et al., 2019; Rezaei Savadkouhi et al., 2020). However, the effect of salt on this parameter has not been studied so far. Here in our work, the DPPH free radical scavenging activity was increased by salt treatment for the leaf and root extracts. Electron donation is an important mechanism in which plants bioactive compounds convert free radicals to nonradical forms and thus, end the radical chain reactions (San Miguel-Chávez, 2017; Shahidi and Ambigaipalan, 2015). By analyzing various plant species, it has been observed that the main component of DPPH scavenging activity is phenolics, flavonoids, and anthocyanins (Fukumoto and Mazza 2000; Kim et al., 2007). Phenolic compounds act as a reducing agent and a hydrogen donator and show antioxidant effects (Oke et al., 2009).

\section{CONCLUSION}

Our data demonstrated that, hyssop plants are a salt-tolerant species, and secondary metabolites are increased upon growth under salinity. Regarding the fact 
that, the plants dry matter production was reduced under higher salt levels. i.e., $200 \mathrm{mM}$ equivalent with 14.5 $\mathrm{dS} \mathrm{m} \mathrm{m}^{-1}$, cultivation of this species is recommended in the soils with electrical conductivity up to $10 \mathrm{dS} \mathrm{m}^{-1}$. Thus, the cultivation of this species on salinized soils that are unsuitable for most crop species is an alternative for lowincome farmers.

\section{REFERENCES}

Acosta-Motos, J. R., Ortuno, M. F., Bernal-Vicente, A., Diaz-Vivancos, P., Sanchez-Blanco, M. J., \& Hernandez, J. A. (2017). Plant responses to salt stress: adaptive mechanisms. Agronomy, 7(1), 18. https://doi.org/10.3390/agronomy7010018

Ahl, S. A., \& Omer, E. (2011). Medicinal and aromatic plants production under salt stress. A review. Herba Polonica, 57(1), 72-87.

Ahmad, P., \& Sharma, S. )2008(. Salt stress and phyto-biochemical responses of plants. Plant and Soil Environment, 54, 89-99. https://doi.org/10.17221/2774-PSE

Akyol, T.Y., Yilmaz, O., Uzilday, B., Uzilday, R. Ö., \& Türkan, İ. (2020). Plant response to salinity: an analysis of ROS formation, signaling, and antioxidant defense. Turkish Journal of Botany, 44(1), 1-3. https://doi.org/10.3906/bot-1911-15

Alam, M. A., Juraimi, A. S., Rafii, M. Y., Hamid, A. A., Aslani, F., \& Alam, M. Z. (2015). Effects of salinity and salinity-induced augmented bioactive compounds in purslane (Portulaca oleracea L.) for possible economical use. Food Chemistry, 169, 439-47. https://doi.org/10.1016/j.foodchem.2014.08.019

Bates, L. S., Waldren, R. P., \& Teare, I. (1973). Rapid determination of free proline for water-stress studies. Plant and Soil, 39(1), 205-207. https://doi.org/10.1007/BF00018060

Becerra-Gudiño, A., Juárez-Rosete, C. R., Bugarín-Montoya, R., \& Murillo-Amador, B. (2019). Growth of Rosmarinus officinalis L. and accumulation of secondary metabolites under high salinity. Revista Bio Ciencias, 6, e567.

Beers, R. F \& Sizer, I. W. (1952). A spectrophotometric method for measuring the breakdown of hydrogen peroxide by catalase. Journal of Biological chemistry, 195(1), 133-140. https://doi.org/10.1016/S0021-9258(19)50881-X

Bistgani, Z. E., Hashemi, M., DaCosta, M., Craker, L., Maggi, F., \& Morshedloo, M. R. (2019). Effect of salinity stress on the physiological characteristics, phenolic compounds and antioxidant activity of Thymus vulgaris L. and Thymus daenensis Celak. Industrial Crops and Products, 135, 311-320. https://doi.org/10.1016/j.indcrop.2019.04.055

Bradford, M. M. (1976). A rapid and sensitive method for the quantitation of microgram quantities of protein utilizing the principle of protein-dye binding. Analytical Biochemistry, 72(1-2), 248-254. https://doi.org/10.1016/00032697(76)90527-3

Chaves, M. M., Flexas, J., \& Pinheiro, C. (2009). Photosynthesis under drought and salt stress: regulation mechanisms from whole plant to cell. Annals of Botany, 103(4), 551-560. https://doi.org/10.1093/aob/mcn125

Cheng, Y., Song, C. (2006). Hydrogen peroxide homeostatis and signaling in plant cells. Science in China, Series C (Life Sciences-English Edition), 49(1), 1.

Dazy, M., Béraud, E., Cotelle, S., Meux, E., Masfaraud, J.F., \& Férard J.F. (2008). Antioxidant enzyme activities as affected by trivalent and hexavalent chromium species in Fontinalis antipyretica Hedw. Chemosphere, 73(3), 281-290. https:// doi.org/10.1016/j.chemosphere.2008.06.044

Dinda, B., Dinda, M., Kulsi, G., Chakraborty, A., \& Dinda S. (2019). Therapeutic potentials of plant iridoids in Alzheimer's and Parkinson's diseases: A review. European Journal of Medicinal Chemistry, 169,185-199. https://doi. org/10.1016/j.ejmech.2019.03.009

Dubois, M., Gilles, K. A., Hamilton, J. K., Rebers, P., \& Smith, F. (1956). Colorimetric method for determination of sugars and related substances. Analytical Chemistry, 28(3): 350356. https://doi.org/10.1021/ac60111a017

El Aziz, M. M., Ashour, A. S., \& Melad, A. S. (2019) A review on saponins from medicinal plants: chemistry, isolation, and determination. Journal of Nanomedicine Research, 8, 6-12.

Fathiazad, F., \& Hamedeyazdan, S. (2011) A review on Hyssopus officinalis L.: Composition and biological activities. African Journal of Pharmacy and Pharmacology, 5(17), 1959-1966 https://doi.org/10.5897/AJPP11.527

Fathiazad, F., Mazandarani, M., \& Hamedeyazdan, S. (2011) Phytochemical analysis and antioxidant activity of Hyssopus officinalis L. from Iran. Advanced Pharmaceutical Bulletin, 1(2), 63.

Flores-de-Santiago, F., Kovacs, J., Wang, J., Flores-Verdugo, F., Zhang, C., \& González-Farías, F. (2016). Examining the influence of seasonality, condition, and species composition on mangrove leaf pigment contents and laboratory based spectroscopy data. Remote Sensing, 8(3), 226-246. https:// doi.org/10.3390/rs8030226

Foyer, C., Descourvieres, P., \& Kunert, K. (1994). Protection against oxygen radicals: an important defence mechanism studied in transgenic plants. Plant Cell Environment, 17(5), 507-523. https://doi.org/10.1111/j.1365-3040.1994. tb00146.x

Fuchs, A., \& Bowers, M. D. (2004). Patterns of iridoid glycoside production and induction in Plantago lanceolata and the importance of plant age. Journal of Chemical Ecology, 30(9), 1723-1741. https://doi. org/10.1023/B:JOEC.0000042398.13765.83

Fukumoto, L. R., \& Mazza, G. (2000). Assessing antioxidant and prooxidant activities of phenolic compounds. Journal of Agricultural and Food Chemistry, 48(8), 3597-3604. https://doi.org/10.1021/jf000220w

Giusti, M. M., Wrolstad, R. E. (2001). Characterization and measurement of anthocyanins by UV-visible spectroscopy. Current Protocols in Food Analytical Chemistry, 00(1), F1.2.1-F1.2.13. https://doi.org/10.1002/0471142913. faf0102s00

Gupta, B., \& Huang B. (2014). Mechanism of salinity tolerance in plants: physiological, biochemical, and molecular characterization. International Journal of Genomics, e701596. https://doi.org/10.1155/2014/701596

Heath, R. L., \& Packer, L. (1968). Photoperoxidation in isolated chloroplasts: I. Kinetics and stoichiometry of fatty acid per- 
oxidation. Archives of Biochemistry and Biophysics, 125(1), 189-198. https://doi.org/10.1016/0003-9861(68)90654-1

Hiai, S., Oura, H., Odaka, Y., \& Nakajima, T. (1975). A colorimetric estimation of ginseng saponins. Planta Medica, 28(8), 363-369. https://doi.org/10.1055/s-0028-1097871

Hristova, Y., Wanner, J., Jirovetz, L., Stappen, I., Iliev, I., \& Gochev, V. (2015). Chemical composition and antifungal activity of essential oil of Hyssopus officinalis L. from Bulgaria against clinical isolates of Candida species. Biotechnol Biotechnol Equip, 29, 592-601. https://doi.org/10.1080/131 02818.2015.1020341

Hussain, H., Green, I. R., Saleem, M., Raza, M. L., \& Nazir, M. (2019). Therapeutic potential of iridoid derivatives: Patent review. Inventions, 4(2), 29. https://doi.org/10.3390/inventions 4020029

Jahantigh, O., Najafi, F., Badi, H. N., Khavari-Nejad, R. A., \& Sanjarian, F. (2016). Changes in antioxidant enzymes activities and proline, total phenol and anthocyanine contents in Hyssopus officinalis L. plants under salt stress. Acta Biologica Hungarica, 67(2), 195-204. https://doi. org/10.1556/018.67.2016.2.7

Kalra, Y. (1997). Handbook of reference methods for plant analysis. CRC press. https://doi.org/10.1201/9781420049398

Kazazi, H., Rezaei, K., Ghotb-Sharif, S. J., Emam-Djomeh, Z., \& Yamini, Y. (2007). Supercriticial fluid extraction of flavors and fragrances from Hyssopus officinalis L. cultivated in Iran. Food Chemistry, 105(2), 805-811. https://doi. org/10.1016/j.foodchem.2007.01.059

Khazaie, H. R., Nadjafi, F., \& Bannayan, M. (2008). Effect of irrigation frequency and planting density on herbage biomass and oil production of thyme (Thymus vulgaris) and hyssop (Hyssopus officinalis). Industrial Crops and Products, 27(3), 315-321. https://doi.org/10.1016/j.indcrop.2007.11.007

Kim, M. J., Hyun, J. N., Kim, J. A., Park, J. C., Kim, M. Y., Kim, J. G., Lee, S. J., Chun, S. C., Chung, I. M. (2007). Relationship between phenolic compounds, anthocyanins content and antioxidant activity in colored barley germplasm. Journal of Agricultural and Food Chemistry, 55(12), 4802-4809. https://doi.org/10.1021/jf0701943

Kotagiri, D., Beebi, S. K., Chaitanya, K. V. (2017). Secondary metabolites and the antimicrobial potential of five different Coleus species in response to salinity stress. BioRxiv, https://doi.org/10.1101/220368

Lin, C. C., \& Kao, C. H. (1999). NaCl induced changes in ionically bound peroxidase activity in roots of rice seedlings. Plant and Soil, 216(1), 147-153. https://doi. org/10.1023/A:1004714506156

Lugan, R., Niogret, M. F., Leport, L., Guégan, J. P., Larher, F. R., Savouré, A., Kopka, J., Bouchereau, A. (2010). Metabolome and water homeostasis analysis of Thellungiella salsuginea suggests that dehydration tolerance is a key response to osmotic stress in this halophyte. The Plant Journal, 64(2), 215229. https://doi.org/10.1111/j.1365-313X.2010.04323.x

Mattioli, R., Costantino, P., Trovato, M. (2009). Proline accumulation in plants: not only stress. Plant Signaling \& Behavior, 4(11), 1016-1018. https://doi.org/10.4161/psb.4.11.9797

Mushtaq, Z., Faizan, S., \& Gulzar, B. (2020). Salt stress, its impacts on plants and the strategies plants are employing against it: a review. Journal of Applied Biology and Biotechnology, 8, 81-91. https://doi.org/10.7324/JABB.2020.80315

Narayanan, P., \& Akamanchi, K. (2003). Colorimetric estimation of total iridoid content of Picrorhiza kurrooa. Journal of Asian Natural Products Research, 5(2), 105-111. https:// doi.org/10.1080/1028602021000054955

Netala, V. R., Ghosh, S. B., Bobbu, P., Anitha, D., \& Tartte, V. (2015). Triterpenoid saponins: a review on biosynthesis, applications and mechanism of their action. International Journal of Pharmacy and Pharmaceutical Sciences, 7(1), 24-28.

Oke, F., Aslim, B., Ozturk, S., \& Altundag, S. (2009). Essential oil composition, antimicrobial and antioxidant activities of Satureja cuneifolia Ten. Food Chemistry, 112(4), 874-879. https://doi.org/10.1016/j.foodchem.2008.06.061

Paiva, E. P., Torres, S. B., Alves, T. R, Sá, F. V., Leite, M. D., \& Dombroski, J. L. (2018). Germination and biochemical components of Salvia hispanica L. seeds at different salinity levels and temperatures. Acta Scientiarum. Agronomy, 40, e39396. https://doi.org/10.4025/actasciagron.v40i1.39396

Parida, A.K., \& Das A.B. (2005). Salt tolerance and salinity effects on plants: a review. Ecotoxicology and Environmental Safety, 60(3), 324-349. https://doi.org/10.1016/j. ecoenv.2004.06.010

Parihar, P., Singh, S., Singh, R., Singh, V.P., \& Prasad, S.M. (2015). Effect of salinity stress on plants and its tolerance strategies: a review. Environmental Science and Pollution Research, 22(6), 4056-4075 https://doi.org/10.1007/ s11356-014-3739-1

Petropoulos, S. A., Levizou, E., Ntatsi, G., Fernandes, Â., Petrotos, K., \& Akoumianakis, K., et al. (2017). Salinity effect on nutritional value, chemical composition and bioactive compounds content of Cichorium spinosum L. Food Chemistry, 214, 129-136. https://doi.org/10.1016/j.foodchem.2016.07.080

Pirbalouti, A. G., Mohamadpoor, H., Bajalan, I., \& Malekpoor, F. (2019). Chemical compositions and antioxidant activity of essential oils from inflorescences of two landraces of hyssop [Hyssopus officinalis L. subsp. angustifolius (Bieb.)] cultivated in Southwestern, Iran. Journal of Essential Oil Bearing Plants, 22(4), 1074-1081. https://doi.org/10.1080/ 0972060X.2019.1641431

Rezaei Savadkouhi, N., Ariaii, P., \& Charmchian Langerodi, M. (2020). The effect of encapsulated plant extract of hyssop (Hyssopus officinalis L.) in biopolymer nanoemulsions of Lepidium perfoliatum and Orchis mascula on controlling oxidative stability of soybean oil. Food Science \& Nutrition, 8(2), 1264-1271. https://doi.org/10.1002/fsn3.1415

Rosa, M., Prado, C., Podazza, G., Interdonato, R., González, J. A., Hilal, M., \& Prado, F. E. (2009). Soluble sugars: Metabolism, sensing and abiotic stress: A complex network in the life of plants. Plant Signaling \& Behavior, 4(5), 388-393. https://doi.org/10.4161/psb.4.5.8294

Salachna, P., Grzeszczuk, M., Meller, E., \& Mizielińska, M. (2019). Effects of gellan oligosaccharide and $\mathrm{NaCl}$ stress on growth, photosynthetic pigments, mineral composition, antioxidant capacity and antimicrobial activity in red perilla. Molecules, 24(21), 3925. https://doi.org/10.3390/ molecules 24213925 
San Miguel-Chávez, R. (2017). Phenolic antioxidant capacity: A review of the state of the art. Phenolic Compounds-Biological Activity, 8, 59-74. https://doi.org/10.5772/66897

Sarkar, K., \& Sil, P. C. (2006). A $43 \mathrm{kDa}$ protein from the herb Cajanus indicus L. protects thioacetamide induced cytotoxicity in hepatocytes. Toxicology in vitro, 20(5), 634-640. https://doi.org/10.1016/j.tiv.2005.11.003

Seevers, P., Daly, J., \& Catedral, F. (1971). The role of peroxidase isozymes in resistance to wheat stem rust disease. Plant Physiology, 48(3), 353-360. https://doi.org/10.1104/ pp.48.3.353

Sergiev, I., Alexieva, V., \& Karanov, E. (1997). Effect of spermine, atrazine and combination between them on some endogenous protective systems and stress markers in plants. Comptes Rendus de l Academie Bulgare des Sciences, 51(3), 121-124.

Sethi, S., Joshi, A., Arora, B., Bhowmik, A., Sharma, R. R., \& Kumar, P. (2020). Significance of FRAP, DPPH, and CUPRAC assays for antioxidant activity determination in apple fruit extracts. European Food Research and Technology, 246(3), 591-598. https://doi.org/10.1007/s00217-020-03432-z

Shahidi, F., \& Ambigaipalan, P. (2015). Phenolics and polyphenolics in foods, beverages and spices: Antioxidant activity and health effects-A review. Journal of Functional Foods, 18, 820-897. https://doi.org/10.1016/j.jff.2015.06.018

Shu-Hsien, H. U., Chih-Wen, Y. U., \& Lin, C. H. (2005). Hydrogen peroxide functions as a stress signal in plants. Botanical Bulletin of Academia Sinica, 46, 1-10.

Sparg, S. G., Light, M. E., Van Staden, J. (2004). Biological activities and distribution of plant saponins. Journal of ethnopharmacology, 94(2-3), 219-243. https://doi.org/10.1016/j. jep.2004.05.016
Taarit, M. B., Msaada, K., Hosni, K., Hammami, M., Kchouk, M. E., Marzouk, B. (2009). Plant growth, essential oil yield and composition of sage (Salvia officinalis L.) fruits cultivated under salt stress conditions. Industrial Crops Production, 30, 333-337. https://doi.org/10.1016/j.indcrop.2009.06.001

Valifard, M., Mohsenzadeh, S., Kholdebarin, B., \& Rowshan, V. (2014). Effects of salt stress on volatile compounds, total phenolic content and antioxidant activities of Salvia mirzayanii. South African Journal of Botany, 93, 92-97. https:// doi.org/10.1016/j.sajb.2014.04.002

Verbruggen, N., \& Hermans, C. (2008). Proline accumulation in plants: a review. Amino acids, 35(4), 753-759. https://doi. org/10.1007/s00726-008-0061-6

Verma, N., \& Shukla, S. (2015). Impact of various factors responsible for fluctuation in plant secondary metabolites. Journal of Applied Research in Medicinal and Aromatic Plants, 2 (4), 105-113. https://doi.org/10.1016/j.jarmap.2015.09.002

Wang, C., Gong, X., Bo, A., Zhang, L., Zhang, M., Zang, E., Zhang, C., \& Li, M. (2020). Iridoids: research advances in their phytochemistry, biological activities, and pharmacokinetics. Molecules, 25(2), 287. https://doi.org/10.3390/ molecules 25020287

Zhishen, J., Mengcheng, T., \& Jianming, W. (1999). The determination of flavonoid contents in mulberry and their scavenging effects on superoxide radicals. Food Chemistry, 64, 555-559. https://doi.org/10.1016/S0308-8146(98)00102-2

Zrig, A., Tounekti, T., Hegab, M. M., Ali, S. O., \& Khemira, H. (2016). Essential oils, amino acids and polyphenols changes in salt-stressed Thymus vulgaris exposed to open-field and shade enclosure. Industrial Crops and Products, 91, 223230. https://doi.org/10.1016/j.indcrop.2016.07.012 